以上の成績から, 心電図で安静時正常, 運動負荷陽性 群からのほ 者が表われやすいといえよう。

そして, 男では加令, 動脈硬化の進展とともに異常心 電困が現われる傾向があるが，女ではその関連は明らか でなかった。

筫問: 花園直人（鳥取大 第 1 内科）(1)潜在性冠不 全の定義は?

(2) 5 年間の間には, 体重調整例などの影響があると思 われるが，この因子について考慮されたか.

答 : 森岡豊嗣 (1)潜在性冠不全については問題が多いが, 一応, 心電図で安静時正常, 運動負荷で ST 降下が水平 型で $0.05 \mathrm{mV}$ から $0.1 \mathrm{mV}$ のものをとった.

(2)体重, 食䬣内容等については, 今後の問題として検 討したい.

筫問 : 前田如矢（大阪市立大 第 1 内科） 1） 5 年 間の経過中の治療との関係はいかが. 5 年間継続治療を 受けている群と, 治療を中断したり無治療であった群と の間に差はみられなかったか。

2) ECG 上安静時もしくは負荷後に虚血性 $\mathrm{ST}-\mathrm{T}$ 変化を示すにかかわらず, 無痛ないし無症状の症例はど のくらいあるか.

答：森岡豊嗣 1） 5 年間経過して治療していたのは, 2,3 例にすぎない.

2 ) 心電困変化があるのに Angina のないものがある と思うがと問に当然のことと思う。

\section{3. 心尖拍動波に関する研究}

一一高血圧症および各種心疾患における異 常 $\mathrm{a}$ 波の程度ならびに出現頻度につ いて

前田正博 原 重樹 竹内伸夫 竹越 裏 村上暎二 村上元孝

$<$ 第 2 内科 $>$

平丸義武 $<$ 公衆衛生学教室 $>$

（金沢大）

ACG について, 健常者・高血圧者・虚血性心疾患お よび各弁膜疾患における異常 $\mathbf{a}$ 波の出現状態を検討し た. a-wave ratioは, 我々のデータからは $12 \%$ 以上 を異常とするのが適当と思われる.これは 50〜60才代 の健常者の平均値 +1 標準偏差から考慮した. 各群にお ける a-wave ratio を比較すると, 健常者で 20〜40才 代と 50〜60才代では後者のほ5が大きかった（ $p<$
0.01). 各疾患群において，それぞれの群に相当する年 代の健常者群と比較すると, 高血圧群・冠不全群・新鮮 心筋硬塞症および MI で増加がみられた（それぞれ $p$ $<0.01)$. また AI でも増加をみた $(p<0.05)$. これに 対して MS では減少がみられた $(t<0.01)$.

a-wave ratio か 12\%を越える頻度を各群において 列記すると, 健常者については 20４0才代 (0/33) 0 $\%$ ，50才代 (4/28) 14\%，60才代 (1/11) 9\%. 異常 者群では高血圧群 (39/63) 64\%, 冠不全 (13/32) $41 \%$, 新鮮心筋硬塞 (8/8) $100 \%$ ，陳旧性硬塞 (4/8) 50\%, MS $(0 / 8) 0 \%$, MI $(6 / 10) 60 \%$, MSI (1/3) $33 \%$, AS (2/4) 50\%, AI (6/11) 54\%, ASI (0/2) 0\%であ った，心電図の電気軸との関係をみると, AI では左軸 方向への変化との間に正の相関がみられた $(p<0.05)$. 大動脈造影に打いて Seller らの分類による逆流程度と の対比をみると, 逆流程度が強い注ど $\mathrm{a}$ 波の増高傾向が みられるが, 重症 AI でも $\mathrm{a}$ 波の増高しない例もあっ た. MS, MI の優位性の臨床的鑑別に, 急速充満波の変 化と合わせて a-wave ratio の差を検討するとき，ACG は有用であると思われる.

\section{4. 心疾患のスクリーニンクにおける心尖 拍陻波の有用性について}

平丸義武、鏡森定信 金川克子 河野俊一 加藤孝之

<公衆衛生学教室 $>$ 村上暎二 村上元孝

$<$ 第 2 内科 $>$ (金沢大)

循環器検診における心疾患のスクリーニングという立 場から心尖拍動波の有用性について検討した，対象は50 〜69才までの男 201 例である. a-wave ratio, Q-E 間 隔 (心電図 $\mathrm{Q}$ 波の始めから $\mathrm{E}$ 点まで)， $\mathrm{C}-\mathrm{E}$ 間隔 (収 縮期波上行脚の始めから $\mathrm{E}$ 点まで）を測定し，他の検 查所見と対比検討した。

1) 正常者 39 例については a-wave ratio, Q-E 間隔, C-E 間隔と $\mathrm{R}-\mathrm{R}$ 間隔に有意の相関を認めなかった.

2 ) 正常者 39 例の平均值, 標準偏差より $\mathrm{a}$ 波は 12 \%以上を異常值と考えるのが適当と思われた。

3 ) 高血圧症, 心電困異常者（異常 $Q$ 波, あるいは $\mathrm{ST}$ - $\mathrm{T}$ 変化を認める者), 心胸比 $50 \%$ 以上の者, 大動 脈の延長あるい情不化を認める者, 眼底高度 異常 者 $\left(\mathrm{H}_{3}\right.$ あるいは $\mathrm{S}_{2}$ 以上), ならびに貧血 ( $\mathrm{Hb} 12 \mathrm{~g} / \mathrm{d} l$ 末 
満）の者で $\mathrm{a}$ 波の増高が認められた。

4 ) 高血圧症に拈いて Q-E 間隔，C-E 間隔は awave ratio と負の相関関係があり, 高血圧症, 心電図 異常者, 心胸比 $50 \%$ 以上の各群で a 波の増高を認めな い者では Q-E 間隔, C-E 間隔の延長傾向がある.

5 ) 高血圧症でほかの検查に異常を認めない者 12 例 中 6 例に $\mathrm{a}$ 波の増高が認められ，心機能低下の早期発見 に有用と思われる.

6 ）対象者全例を心尖拍動波異常群, 正常群に分けて 検討した成績は次の機会に報告する。

問: 外畑 篇（名大 中検）正常人での a-wave ratio の分布をみると, かなり右へ skew しているよう だが，その平均値士標準偏差で正常上限を決定するのは 少し問題があると思うが。

答：平丸義武 対数正規確率紙を使用して, 正常者, 心電図異常者について検討したふるい分けの点を, 正常 者の平均值, 標準偏差から考えられる点と両方を考虑し て，a 波は $12 \%$ 以上を異常值とするのが適当であると 考えた。

問 : 前田如矢（大阪市立大 第 1 内科）心尖拍動 図は記録条件がかなりむずかしく， basal ないし near basal な条件でとることが必要であり，波形の類似性も 各例でコンスタントに得ることはむずかしい.

測定は何心拍以上について実施されたか。また R-R による補正を要すると思うがこの点はいかが。

答 : 平丸義武 測定は少なくとも 3 心拍以上, 平均し て 4〜5心拍について行い, これらの平均值について Q-E， C-E，a-wave ratio と R-R 間隔との相関を検討 したが，有意の相関は認められなかった.

\section{5. 循環器集団検診における心軋図異常之 その予後}

阿部秀逸 塩入綾夫

（宮城県心藏血管病予防協会）

山形做一 佐々木陸郎 藤井功衛 市川 湛 山極洪紹

(東北大 山形内科)

昭和 42 年から 45 年までの 4 年間に宮城県下の成人 約 137, 000 名の循環器検診を実施し，70\%にあたる 95, 000 名の心電図撮影を行い, これらについて人口動 態調查票をもとに, 昭和 45 年末まで脳出血, 脳硬塞, 心臓疾患によって死亡した 785 名を対象に心電困所見か らみた予後について検討した。
心電図は Minnesota Code に準じて判定したが，左 室肥大に関しては Sokolow-Lyon の基準と VAT 0.05 sec 以上の両方を満足した場合のみ左室肥大とした.

心電図異常率は $29 \%$ であり，心電図異常者の中から 死亡したものが $2.7 \%$ あった，心電図異常所見別に死亡 率の高率なるのから順にみると, 心房粗細動 $8 \%$, 左室 肥大 7.9\%, 肺性 P 5\%, 房室ブロック, 右脚ブロック 各 $4.8 \%$, 洞頻脈, 心筋硬塞各 4\%, 期外収縮 3.3\%, 心筋傷害 $3 \%$, 左脚ブロック $2.6 \%$, 洞徐脈 $1.1 \%$, そ の他 $1.9 \%$ となる. 心電図異常所見に対する脳出血, 脳 硬塞，心臓疾患の三つの死因別に死亡率をみたるのでは， 脳出血による死亡は心筋傷害, 左室肥大の所見を呈した ものに多く, 心房粗細動, 左脚ブロック, 心筋硬塞のも のには少ない.また房室ブロック, 肺性 $\mathrm{P}$ の所見者に は脸出血による死亡は 1 例もなかった.

ats

脳硬塞による死亡の場合は各所見ごとにほぼ平均化し ており，とくに目立つ傾向はなかった。，臟病による死 亡は心房粗細動, 房室ブロック, 心筋硬塞, 肺性 $\mathrm{P}$ の 所胃を呈したものに多く, 洞徐脈, 心筋傷害, 左室肥大 のものに少なかった.

以上のことから心電図所見では従来高度異常とみられ ていた左脚ブロックや心筋硬塞などの死亡率より, 比較 的軽度の変化とみられている洞頻脈, 右脚ブロック, 左 室肥大, 肺性 P などの所見を呈したものの予後が悪く, 今後高血圧管理のための心電図異常所見の評価に一考の 必要があると考える。

86. 田主丸 (農村), 牛深 (漁村) におけ る 10 年間の経験よりみた “マスター 2 階段 2 重負荷亡予後之の関係”

木村 登 戸嶋裕德 中山裕熙 田代寛美 （久留米大 木村内科）

マスター 2 階段昇降試験は本来潜在性の虚血性心臟病 を見出す目的で用いられている.このマスター 2 階段 2 重負荷（マスターダブル負荷と略）をフィールドにて用 い, その運動負荷後の心電図と予後との関係を検討した. この報告は私どもが 1958 年来疫学的研究を行ってき た田主丸，牛深地区の 10 年間の経験に基づくものであ る.

[方法]対象は初回調査時 40 才から 64 才までの男子 で安静時正常心電図を示す 817 名, 安静時異常心電図を 示す 23 名である.これらに対し安静時の心電図所見の いかんにかかわらず初回，5 年目と延べ 1,527 回のマス 


\section{一 般}

ターダブル負荷を行った. 判定基準は, 安静時異常心電 図も合わせ検討したので私どもが虚血性心臟病の積極的 運動負荷療法に用いている基準, (1) ST の $1 \mathrm{~mm}$ 以上 の低下あるいは上昇, (2)重症不整脈の出現, (3陽性 $\mathrm{T}$ 波の陰性化あるいは陰性 $\mathrm{T}$ 波の陰性度の増大, (4) U 波 の陰性化, (5)過性脚ブロックの出現, を用いた.

[結果]初回, 5 年目と 2 回の調査時に安静時正常心電 図を示した 1,467 例はマスターダブル負荷により 1,432 例が負荷陰性で，そのうちから 5 年間に $5 \%$ の発症がみ られた。これに反し 35 例の陽性例からは $37 \%$ の発症 がみられた. 安静時異常を示したものは同様 2 回の調査 時に 60 例がマスターダブル負荷を終了した． 37 例の 陰性のbのから $5 \% ， 23$ 例の陽性から 30\% の発症が みられた。 また発症者の内訳では安静時正常心電図で負 荷陽性は脳心事故ともに陰性のものより多いが, やはり 安静時異常で負荷陽性からは心事故が多かった.

〔総括】 安静時心電図の所見のいかんを問わずにマスタ 一ダブル負荷を行い, その後の 5 年間の予後から, マス ターダブル負荷陽性は陰性に比し 7 倍の発症率を有する こと, および陽性のものは心事故のみならず脳事故に対 しても発症要因となりらることを知った。

問：小町喜男（大阪成人病七ンター） Master の 2 段階負荷試験を field で大々的に行われているが，そ の場合, 負荷により心房細動発作, あるいは心事故の発 生はなかったか.

答: 中山裕熙 フィールドにてマスターダブル負荷に より心房細動を起こした症例は経験ない。

追加：木村 登 ブラックバーンがフィールドでの負 荷試験の安全性について非常に多くの数において確かめ ているので, あまり気にしなくてもよいと思う。

\section{7. 高血压症を中心とする循環器疾患の予 後学的研究}

松崎俊久 佐久間德寿

（東京都総務局 衛生管理課）

東京都職員 40 才以上 24,000 名を正常血圧 (I 群), 軽度高血圧 (160/95 以上・II 群), 高度高血圧 $(200 / 110$ 以上・III群)の 3 群に分けて ramdom sampling を行 い, 各群よりほほ均等に抽出された 1,460 名に循環器精 検を繰り返し 10 年間 follow up し，90\% に当る 1,323 名の予後を調査しえた. 10 年間の死亡は 293 名(20\%) で, 死因の5ち 66.5\% 195 名は循環器疾患で, 脳死 124 名 (42.3\%) - 心死 61 名 $(20.8 \%)$ - 腎死 10 名
演題

$9: 185$

(3.4\%) で, 循環器疾患死亡率は 10 年間に正常血 圧 に対し III 群 6 倍・III群 12 倍である. 生存者を含む脳出 血は而群では 40 70 代ではぼ均等の発生率, I ・ II 群 では 70 才代にはほとんどみられない，肥満との関連は なく, 飲酒との関連は軽度に傾向を認め, 喫煙量・血清 コレステロール值には無関係である. 眼底変化との関連 は有意である.脳硬塞は I 群では 60 才代以前ではほと んどみられず，II・II群では加令に伴い急増する．肥満・ 喫煙量・眼底・心電図 $\mathrm{ST} \cdot \mathrm{T}$ 変化との関連は有意であ る. 心筋硬塞は I ・ II ・ III各群ともに加令に上る増加を 認め, 肥満・喫煙量 · 心胸比 · 心電図 $\mathrm{ST} \cdot \mathrm{T}$ 变化との 関連は有意である.

脳出血・脳硬塞・心筋硬塞はともに血圧の增加につれ て多発するが，降圧剤の継続服用により脳出血の発生率 は約 $1 / 3$ になり, 脳硬塞では同様の傾向を認めるが有意で はなく，心筋硬塞と降圧剤服用は一定の関係を示さない。

\section{8. 大分県心䑏障害者の自然糜に関する研} 究 (その 2)

児玉俊一<循環器科>

末松 祐 植田太郎 古城正人 山下英文 中根正勝 $<$ 内科 $>$

（国立別府病院）

大分県下各地の住民検診の間接レントゲン写真の心肺 比を計測して，60\% 以上の明らかな心疾患をひろいだ し, 打聴診, 心電図, 胸部直接写真, その他により診断 を行い, 年令階層に打ける先天性, リウマチ性および虚 血性高血圧性心臟病の頻度を調査している。

心肺比 $60 \%$ 以上で， NYHA 分類 4 度， 3 度のもの は心蔵機能障害による身体障害等級 1 級扣よび 3 級に該 当するので，身障者手帳をもたせることで行政への橋渡 しと本人への経済的恩恵が得られ，またフォローアップ もしやすくなる利点がある。

これまでに別府市（総人口 121,577)，院内町 $(8,615)$ ， 国東町 $(19,656)$, 豊後高田保健所管内 (4 市町村, 36,631 ), 三重保健所管内 (8 町村, 70,856) を調べた. 検診の受診者数はそれぞれ 16,466（受診率 $40 \%$ ）（勤 務者, 生徒学生は該当しない)，6,129 (99\%)， 3,565

(72\%), 8, 997 (98\%), 20, $276(78 \%)$ で合計 55, 392. この中で心肺比 $60 \%$ 以上のものは別府市では 56 (5 ち高血圧, 虚血性 41 , リウマチ性 12 , その他 3 ) 受診 者に占める割合は $3.4 \%$ ，院内町 13 （それぞれ 8,4 , 
$9: 186$

日本老年医学会雑誌

1) $3.6 \%$, 国東町 $36(30,5,1) 5.9 \%$, 高田地区 87 (69，13，5） 9.6\%，三重地区 $72(62 ， 5 ， 5) 3.6 \%$.

年令別にみると 40 才代で 1 〜 \% 50 才代で $2 \sim 5$ \%，60 才代 5～10\%，80 才代 15～30\% と率が増えて いく傾向がみられ，リウマチ性心臓病によるものはだい たい 60 才代まで，ごく少数が 70 才代初まで存在する. 一方高血圧性虚血性心臟病によるものは 50 才代より増 加して高令まで存在する.ささら今後調查と追跡を続け たい.

\section{9. 地域，職域別にみた脳心事故発症因子 の差異についての検討}

高橋 弘 飯田 稔 島本 喬 近山行夫 小西正光 小町喜男

（大阪成人病センター）

生活習慣の相違による脳心事故の発生要因の差異を検 討するため(1)秋田県農村住民 2,593 (2)大阪農村住民 647 (3)大阪都市近郊住民3,324(4)大阪事業所一般従業員 4,450 (5)同管理職 373 の 5 群計 11,387 名について 5 年間の追 跡調査を行い, prospective studyにより脳心事故の発 症因子を明らかにすることに努めた。 5 年間の脳卒中新 発生数はおの括の $109,14,25,25,6$ の計 179 例, 心事 故は 5 群計 20 例である. 血圧, 心電図, 眼底所見の組 み合わせのパターン別にみると, 高血圧群の中でも眼底, 心電図ともに高血圧性変化を示するのからの脳卒中発生 率が 5 群計で 26.32 ともっとも高く（全所見群から 2. 78) 高血圧のみの群の約 6 倍, 3 項目とも正常な群の 約 35 倍の発症をみている. 集団別にみると秋田の 43.56 を筆頭に(1)（4)の各集団でこの所見群からの発生がもっ とも高率であるが，管理職群ではやや特異的で心電図虚 血性変化を伴う高血圧群からの発症が多い. 次に肥満, 高脂血症と脳心事故の関連をみると, 全集団計では脸卒 中は肥満, 高脂血症を伴わない群からの発症のほうが明 らかに高率である。この傾向は(1)(2)農村部のみならず, (3(4)のよ5な都市の平均的生活様式を営むものの集団に おいてもかわらず, ただ管理職群のみは肥満, 高脂血症 を伴う高血圧者からの発症が多くなっている. 心事故は 全般に低率であるが肥満, 高脂血症を有するものからの 発症が多く，管理職群でもっとも高率である.

したがって生活習慣の都市化の非常に進んだ集団では 脳心事故発症因子に質的な差があるといえるが，一般に は肥満, 高脂血症のとくに脳卒中発症に及ばす影響は少 なく, 高血圧者の生活指導はこの点を考慮して行ら必要
9 巻 3 号 $(1972: 5)$

がある。

問 : 堀 正二（阪大 第 1 内科）肥満者の高血圧 者の眼底所見の動脈硬化度は, 非肥満者の硬化度に比し 軽度か. そうなら, 肥満度と逆相関するか.

答 : 高橋 弘 主として昨年の本学会で報告したが, 肥満者は高血圧にはなりやすいが眼底異常の合併率は少 ない．この事実は断面調査のみでなく追跡調査によって も確認している.

\section{0. 同一県内の脳卒中死亡來の異なる二地 区での疫学調查の比較}

伊藤敬一 岩㴊貴之 古徳利光 渡辺勝宏 小山恵子 沓沢少之 中村 隆

（秋田県立脳血管研究所）

一つの県内で脳卒中死亡率の異なる地区があれば,こ のような接近している 2 地区間では気候，習慣など，い くつかの parameterを共通因子とみなすことが可能なの で, 両地区の疫学調査の比較は, 脳卒中多発の要因を分 析する 1 手段として種々の利点をもっている．私どもは， 秋田県下の比較的死亡率の低い天王町 (219/人口 10 万) と, 高い雄和村 (361/人口 10 万) の中からおのおの人 口千人程度の部落を選び断面調查を行い比較したので報 告する.

1) 血圧: 年令別平均值では, 雄和は天王に比し男女 とも収縮期血圧で 15 20 $\mathrm{mmHg}$, 拡張期血圧で $10 \mathrm{~mm}$ $\mathrm{Hg}$ 程度高值を示した. さらに，WHO の基準に基つくく 高血圧者の頻度でも，雄和は天王より高頻度であった。

2）血清コレステロール：男女とも両地区間に差は認め られなかった３）中性脂肪：男女とも，むしろ脳卒中 死亡率の低い天王のほうが高い傾向を示した４）脂酸 分画 $(\mathrm{L} / \mathrm{O}$ 比): 年令別平均值で比較すると, 天王がむ しろ 30〜40 才代で低下傾向を示した．5）頭蓋内動脈 壁石灭化頻度: 雄和は 40 才代 $2.8,50$ 才代 $13.0,60$ 才代 $29.1 \%$ ，天王は 40 才代 $1.1,50$ 才代 $11.0,60$ 才代 $21.6 \%$ で両地区間に推計学上有意差は認められな かった，6）眼底所見：Scheie の硬化性変化 II および III以上の頻度を比較すると, 雄和が各年代ともわずかに 高いが推計学上の差はなかった.

以上の成績から, 上記の諸因子の中で, とくに脳卒中 多発との関連性を示唆したのは血圧値だけであった。 


\section{一 般}

91. 地域集団で新たに発生した脳卒中の危

険因子の多变量解析による評価

堀部 博 早川式彦 青木伸雄 岡田 博

(名大 予防医学)

目的 : 長年追跡調查を行っている愛知県の赤羽根町・ 旭町で，1964〜1970 年に新たに 発症した脳卒中発作例 につき, その初診時所見を中心に, 相対危険度と多変量 解析により比較検討する.

対象と方法 : 上記 7 年間に発生した脳出血発作は 136 , 脳血栓発作は 108，その他が 20. 万ち 24 因子に欠測 值のない脳出血 51 例とその対照 204 例, 脳血栓 36 例 とその対照 144 例が分析の対象. 対照は, 脳卒中発作を 起こしたことがない生存者の中から発作例と町・性・年 令を対応させた．今回は肥瘦度・尿蛋白・随時血圧・安 静時心電図の $\mathrm{R}$ 波増高と $\mathrm{ST} \cdot \mathrm{T}$ 所胃 - 眼底の高血圧 所見と硬化性所見・血清総コレステロール・喫煙・飲酒 の 12 因子につき $2 〜 4$ のカテゴリーに分け, 林氏の要 因分析（II）を適用.

結果と考案 : (1)相対危険度の計算では把握されていな い新しい事実が, 要因分析で浮上ってくることが判明. (2)一般的には要因分析で得られた結果は，相対危険度に もかなり反映しているといえる。（3両分析とも収縮期圧 が高ければ高いほど脳出血は起きやすい．脸血栓は相対 危険度ではそ5だが，要因分析では 180 ミリ以上で数量 值が下っている. (4)心電図 $\mathrm{R}$ 波増高は脳血栓より脸出 血との関連が深く, $\mathrm{ST} \cdot \mathrm{T}$ 異常は相対危険度では脳出 血との関連がより高かったが, 要因分析では予測どおり 脳血栓との関係がより深い. (5)血清総ュレステロールは いずれの分析でも，脳出血・血栓いずれとも関係がない. (6)その他の因子については相対危険度とほぼ同じ結果が 得られた。(7)多変量解析は正確な診断と精密な情報・適 切な仮説によって初めて生きる.

問 : 関 一郎（大阪医大 第 1 内科） $(89,91$ に 対して）血清コレステロール値を栄養の指数と考える場 合，どの位を正常值の目標とすべきか，お教えください。

追加：木村 登（久留米大） (1)肥満した高血圧者に 脳出血が少ないとのご発表は重要な事実であると思う。

これは私どもの農村と漁村の追跡の成績でも同様である. これの一つの理由は蛋白捸取が少なすぎるため, 農村の やせた人には血清蛋白量および AG 比が異常に低い場合 が多いことであると思うので, 今後の疫学調査にはそれ の測定をやっていただきたい，この異常㔻白血症が脳出 血の一つの成因ではないかと思われる.
演題

$9: 187$

(2)血清コレステロールの正常の上界は $170 \mathrm{mg} / \mathrm{d} l$, 異 常の下界は $220 \mathrm{mg} / \mathrm{d} l$ としたらと考えている.

92. 久山町における壮・老年者の心理学的 検查成績

岡山昌弘 竹下司恭 尾前照雄

$$
\begin{gathered}
\text { (九州大 第 } 2 \text { 内科) } \\
\text { 広田安夫 } \\
\text { (九州曾大 内科) } \\
\text { 勝木司馬之助 } \\
\text { (九州中央病院) }
\end{gathered}
$$

久山町住民の5ち, 明らかな脳障害, 視力障害のない 40〜80 才代の壮・老年者に Trail Making Test (TM T), Porteus Maze Test (PMT) の二つの心理テスト を，4年の間隔をおいて 2 回行った. 2 回ともテストの できた TMT 952 例, PMT 73 例の成績を綐断的, テ スト別，性別および年令別に比較検討した，TMTでは 加令によって成績は悪化し，女性は男性よりも成績悪く， Part IIの成績は Part I のそれょりも悪かった。 また 2 回目のテスト成績が良くなった率 (練習効果) が加令 とともに減少の傾向を示した.

PMT においても加令による悪化と男性の成績が，女 性のそれよりやや良い傾向がみられた。また 4 年間の間 隔でその test aze の平均に改善も悪化もみられなかっ た.

これらのテスト成績において，1回目から不良のもの， 2 回目で著しく悪化を示したものから将来脳血管性障害 が起こりやすいかどうか, 今後も追求を続ける予定であ る.

留問：梶谷文彦（阪大工学部）動脈硬化時におけ る「ボケ」などに関連して，心理学的検查を施行するこ とは興味ある方法であると思うが, この際これらの検査 成績に影響を与えると思 5 知能, 環境などの因子を除去 する方法を考えておられるか。

答 : 岡山昌弘 それに対してとくに良い方法は私もも ち合わせていない。 
$9: 188$

日本老年医学会雑誌

93. 老年者の健康管理に関する研究（第 1 報）

古川俊之 額田忠篤 稲田 紘 山内良紘

阿部 裕

(阪大 第 1 内科)

吉川博通 佐藤 忠

（住友生命）

梶谷文彦

(阪大工学部電子工学科)

老年者の健康管理のためには老化現象を数量的に把握 することが重要である．このため, 種々の臟器機能值や 運動機能值をパラメータとして使用し, 重回帰式や数量 化理論などの多变量解析論における諸手法を応用して解 析し, 生物学的年令を算出, これを老年者の健康管理に 応用することを試みてきた。

今回は，老年者に多い高血圧・動脈硬化症の患者を対 象とした健康管理のため, これら疾患の経時変化に影響 を及ぼす種々の因子の解析を試みるとともに，従来用い ていなかった心理的パラメータを加味する目的で, 矢田 部一ギルフォード性格検査を実施した。

高血圧・動脈硬化症に影響する因子の解析には大阪大 学第 1 内科外来にて, 1965 年から 1970 年にわたって follow-up した約 50 例のデータを用いた. すなわち, 調查した約 40 項目のパラメータから年令や血糖值，コ レステロールなどの検查值，および投与した各種降圧剂 など 11 項目のパラメータを選び，これらが血圧拉よび 動脈硬化に及ばす影響をパス解析により分析し，それぞ れのパス係数を求め比較検討の結果, 鎮静剂が血圧降下 に相当な効果を有することなど，有用な結果が得られた。

一方, 矢田部一ギルフォード性格検査を老年の高血圧 ・動脈硬化症患者に実施した結果, 対照として行った若 年者や心臟病, 腎臟病など他の循環器疾患老年者の成績 に比較して, 不安定, 不適応, 消極型である $\mathrm{E}$ 型がかな り多いことなどがわかり，この検查を老年者の健康管理 方式にとり入れることの意義が示唆されるとともに，こ れに多変量解析論の手法をとり入れれば，さらに詳細な 分析が可能となることが期待されるとの結論を得た.

問：小町喜男（大阪成人病センター）1）分析は どのような性格の集団について行われたか。

2) Multiphasic な examination に対する planning を考えて扔られるように思らが，生活環境などの相異を 考虑に入れておられるかどうか。

答: 稲田 紘 今回は阪大病院第 1 内科受診の外来患 者の調查データを用いた．各患者の住居環境や職場環境
9 巻 3 号 $(1972: 5)$

などについて細かい分析をしていないため環境 group 別の結果はだしていないが，これらを層別して実施すれ ば，今回用いたのと同じ方式で可能になると思われる.

\section{4.一般標準化からみた老令人ロと死亡に 関する考察}

伊藤志真子 根岸龍雄 秋山房雄

(東大 成人保健学教室)

標準化の概念は荷重平均の考え方であり，これを一般 化することが可能である. 老令人口および成人病死亡と 社会経済的背景との関係を, 都道府県を単位とした一般 標準化により検討した。 またこのための FORTRAN IVプログラムを開発した。昭和 40 年の 60 才以上人口 を昭和 10 年の各指標で標準化した結果, 総人口当り老 令人口は，粗率でみた場合に比較して標準化率で千人当 り約 2 名増加している. また医師数分布に上る標準化率 を計算すると，昭和 10 年の医師当り老令人口粗率 88.4 人, 昭和 40 年 89.2 人に対し, 86.5 人となり, 老令 者に対する医師数は必ずしも減少しているとはい党ない もののよ5である。昭和 40 年の 60 才以上人口は, 医 師数との関係でい壳ば昭和 10 年の 62 才以上人口に当 り, 逆に昭和 10 年の 60 才以上人口は昭和 40 年の 58 才以上人口に当る. 次に脳出血, 悪性新生物, 心疾患な ぞ高令者で問題となる各疾患別死亡を 60 才以上人口で 標準化すると, 老令人口当りの脳出血死亡, 老衰死亡は, 老令人口分布が昭和 10 年と等しい場合の標準化率と比 較して減少しており，逆に悪性新生物，結核，自殺では 増加し, 心疾患では变化がない.成人病の死亡割合は, 総人口打よび医師当り人口で標準化してみると, 脳出血 で減少し心疾患でその割合が増加する. 60 才以上人口 で標準化すると，悪性新生物で増加する.

標準化概念の一般化は, 以上のような老令人口および 死亡の社会経済的背景のもとでの検討に打いても，一つ の手がかりを提供するものと思われる.

留問：梶谷文彦（阪大 工学部）標準化の具体的方 法およびその merit についてのご意見はいかが.

答 : 伊藤志真子 標準化の式は

$$
\frac{\sum_{1}^{n}(\mathrm{n} \text { 才死亡数 }) \times \frac{\mathrm{B} \text { 集団 } \mathrm{n} \text { 才人口 }}{\mathrm{A} \text { 集団 } \mathrm{n} \text { 才人口 }}}{\sum_{1}^{\mathrm{n}} \mathrm{B} \text { 集団 } \mathrm{n} \text { 才人口 }}
$$

この死亡，人口，集団を任意にかえる. 


\section{一 般}

95. 100 才長寿者の循環器系の経年追跡調 查と死にいたる経過

福田正臣

（鹿児島市立病院循環器内科）

100 才以上の長寿者 6 人について, 100 才〜 107 才の 初診以来 $2 \sim 6$ 年間主に心血管系について追跡調查を行 いまたその5ちこの期間中に死亡した 3 例については 死にいたる経過を観察した. 生存の 3 例は現在 105 才

(男), 106 才 (男), 102 才（女）であり, 男 2 人は今 なお農作業を行い, 女 1 人は屋内生活である. 血圧は 3 例とも正常範囲で現在もかわらず, 心電図は洞性不整脈, P-Q 延長, ST の降下等があるがそれ以上に進展变化 せず，末梢動脈の拍動も左右同大でかわりがない。

死亡した 3 例については，2 例は肺炎を思わせる症状 で数日内に死亡し，5ち1例は剖検によってこれを認め た． 1 例は急死 (109 才) で死因は不明である.これら 3 例とも死亡前数年間は心血管系の検査所見に特記すべ き異常はなかった。

\section{6. 死亡構造と就業構造}

内藤雅子 根岸龍雄 秋山房雄

(東大 成人保健学教室)

疾病ないし死亡構造の解明において, それらの变遷が 問題となる. 今回はとくに 65 才以上の男子の死亡構造 と就業構造の推移に注目して, それらの推移確率行列を 求め若干の検討を試みた。なお，演算は FORTRAN IV プログラムを作成し, 東大大型計算センター HITA C 5020 E により行った.

総理府「就業構造基本調査報告」より就業者数, 無就 業者数を都道府県別に得て, 昭和 31 年から 37 年にかけ て就業構造がどのように推移したかを求めたところ, 継 続して就業する確率は 0.82 , 就業から無就業へは 0.18 , 無就業から就業へは 0.16 , 無就業に止まるのが 0.84 と 推定された. また, 昭和 37 年から 43 年にかけての推 移確率は扮の扮の $0.88,0.12 ， 0.18 ， 0.82$ であった. 一方, 昭和 31 年から 43 年への死亡構造の推移確率は 以下のごとくであった。すなわち, 全死因を 9 群（1)全 結核, (2)悪性新生物, (3)脳血管系疾患, (4)心疾患, (5)肺 炎・気管支炎・胃炎・腸炎等, (6)精神病の記載のない老 衰, (7)不虑の事故, (8自殺, (9その他) に分類したとき， (6をのぞいた他の群から(2)，(3)，(4)，(6へへの推移確率は きわめて高い值を示した，(2)から(2)へは 0.70，(4)へは 0.16, (3)から(3)へは 0.70, (4)へは 0.14, (4)から(2)へは
0.26，(3)へは 0, (4)へ 0.19, (7)から(2)へ 0.88 , (3)へ 0.12 等であった.

以上のように 65 才以上の男子では, この 12 年間に 覀性新生物, 脳血管系疾患への死亡推移確率が増加する とともに就業構造においても, 継続して就業する者, 無 就業者が就業する確率も増加し, 死亡構造の推移と就業 構造の推移との間に, 結合確率分布の存在が認められる ことがわかったまた，(3から(4)への推移確率が 0.14 であるのに対して(4)から(3へは０であることが注目され る.

問 : 梶谷文彦（阪大 工学部） 1 ）推移確率の变 動に, 社会的因子を加えた「モデル」の作成はできない ものか.

答 : 内藤雅子 社会経済的諸要因の変動の側面は, こ のモデルによる推移確率の変動から伺うことができる.

また，林氏の数量化モデルの導入も考えられるが，すで に我々は昭和 44 年の民族衛生学会, その他の学会にお いてこの手法を導入し検討した結果を報告した.

\section{7. 高脂血症の分類に関する研究 (XIII)}

梅里継時 五島雄一郎 中村治雄

(慶大 内科)

秋山実近江 明

（富士銀行 健康管理センター）

事務を主とする東京都内の某職域に拈いて 40 才以上 の者に成人病検診を行い, 1969 年, 1970 年の 2 年度連 続受診した者のうち，検尿，肝機能異常者，糖尿病をは じめ血清脂質に影響を与える疾患を有するものを除外し た 1,234 名の男女について, 経時的観察を行った. 早朝 空腹時に採血し，コレステロールを Autoanalyzer, Zurcoueski 法, トリグリセライドを Carlson, Fletcher 法 にて測定し，Fredrickson-慶大変法にて分類した．年令 構成では 40 才〜55 才が約 $98 \%$ を占め，男女別では 男子 $86 \%$ ，女子 $14 \%$ であった。高脂血症の頻度は，昨 年度 $30.2 \%$, 本年度 $42.9 \%$ と増加傾向を示した. Type 別では, Type 0, IIの減少傾向, Type III, IVの増加傾 向を示した. Type の移行については, 本年度各 Typeに ついて昨年度の Type 別由来をみると, Type 0 由来の ものが首位を示した，昨年度の各 Type についてその移 行をみると, 正常者よりその $32 \%$ に及ぶ高脂血症者が 発生しことに Type Iにに多い傾向を示した，血清脂質 について，昨年度の Type 別を基準にして同一人の経過 をみると，コレステロール， TG 值とも高值を示するの 
は低下傾向，低值を示するのは増加傾向を認めた．肥満 との関連では，コレステロール值と相関関係を認めず， TG 做は正常群, 高脂血症群ともに肥満とともに TG の著明な上昇傾向を示し，とくに高脂血症群にて著明で あった，血圧との関連では，コレステロールは相関関係 は認めず, TG 值は収縮期, 拡張期圧とも血圧の上昇と ともに増加傾向を認め, 高脂血症群において著しい傾向 を示した．加令による脂質の変化は，コレステロールで 俚正常群および男子の高脂血症群で加令とともに上昇傾 向を認めたが, TG 值では一定の傾向を認めなかった.

問 : 中村舫久（熊本大 体質医研） 経時的に高コ レステロール血症者が減少しているようだが, 年々食生 活の欧米化という点からはこれに反するデータのようで ある．健康管理の面で食事指導をかなり㛜格に行われた ためだろらか。 それとも管理対象者の食事傾向が，年々 淡白になるためだろうか。

答 : 中村治雄 高コレステロール血症例には, パンフ レット配布、栄養士による食事指導など, かなり厳しい 栄養指導を行っているため, 軽度の高コレステロール血 症例が減少したものと考える。

問：佐々木英夫（新潟大 松岡内科）山村部の chol. の季節的変動が食事の影響によるとのご意見だが, 最近都市部では食事の季節的変化が非常に少ない傾向に あると思われるので, 都市部での cholesterol の季節変 動をみておられたら打教え願いたい。

答 : 梅里継時 (1)高コレステロール血症者の減少傾向 の原因は, 健康管理指導により正常者に復したものが多 数を占めること, および軽度の高コレステロール血症者 が多数を占めていることによると思われる.

(2)コレステロールの都会における季節変動については， 近年の成人病検診でも，また昭和 34 年より経過を追っ た成績でも，各季節に測定していないためか，はっきり した結果は得られていない。

問：木畑正義（岡山大 平木内科） Artoron 投与 による体重，肝機能とくにトランスアミナーゼに対する 影響はいかが. また thrombosis 発生はないが，逆に bleeding が多いのではないか

答 : 都島基夫 GOT, GPT に関して，24 カ月では 現在測定中だが，18 カ月の結果ではまったくGOT, GPT の上昇はみられず，アルトロン $3 \mathrm{Tab} て ゙ は$ 肝障 害を認めないと考えている，前の質問に対しては，まだ 短期間でもあり，これが断定的な結論とは思っていない が，アルトロン投与群にいくぶん肥満の傾向を認めてい
る.

\section{8. 高脂血症の疫学}

都島基夫 五島雄一郎 中村治雄 浅野英一郎

$$
\begin{gathered}
\text { 重松 洋 入江 昇 } \\
\text { (慶大 内科) } \\
\text { 川村 顕 } \\
\text { (東歯大市川病院) } \\
\text { 北村雄哉 } \\
\text { (魚沼総合病院) }
\end{gathered}
$$

昭和 44 年 8 月より高脂血症の疫学的調査を行い, 2 年間の血中脂質の変動, ならびに動脈硬化性疾患の発生 頻度などにつき，(A) Artoron十食餌指導群，(B) Artoron 群, (C) Placebo+食餌指導群, (D) Placebo 群の 4 群に分けて検討した。(1)アルトロン投与群において血 中脂質の低下を認めるが，血中コレステロール濃度では 季節変動が著明で，これは食事のコレステロール摂取量， 脂肪の摂取量が夏に多く冬に少ないことと関連があると 思われる.中性脂肪濃度はアルトロン投与群に拉いて 1 カ月， 6 カ月で有意の低下を示すがその後は前值にもど る Escape の現象を認める. (2)食事指導の影響は, 中性 脂肪およびュレステロール・エステルのパルミチン酸の 減少とリノール酸の増加を認めるが，それぞれ脂質濃度 には反映していない，また皮下脂肪の脂酸構成には，食 事の影響はまだ認めていない。(3)死亡率，有病率に関し ては, Artoron 投与群において脳血栓・心筋硬塞の発生 を認めない，各発生例の危険因子を分析してみると，脳 血栓 3 例中 2 例に拈いて高コレステロール血症を認め, 脳出血においては 9 例中 5 例において高血圧, 肥満を認 めるため，それぞれ密接な関係があると思われる．心筋 硬塞 2 例では一定の傾向を認めていない，食事指導やア ルトロンのような薬段で血中脂質を低下させることによ り，動脈硬化性疾患を予防できる可能性が考えられるが, 本調查はまだ短期間でもあり，本調査をさらに継続して 後日の問題にしたい.

追加：五島雄一郎 この調查に拈いては高血圧者に対 する血圧のコントロールは行っていない、したがって Artoron 投与群, 非投与群から脸出血の発生がみられて いるので, 今後血圧のコントロールも考えている. 


\section{9. 高脂血症の疫学的研究}

一その成因面からの考察—

德久隆成 三瀬淳一 阪口竜平 和田一成

久保文孝 山本 徹 村上紘一

（山口大 三瀬内科）

生化学的な高脂血症の成因研究に関連して, 某大企業 男子社員 $20 \sim 59$ 才, 322 例について疫学的調査を行い, 血清 TG レベルおよび pre- $\beta$ リポ蛋白電気泳動像に影 響を及ぼすと考学られる因子について，推計学的考察を 試みた. 要因分析の結果, TG レベルはコレステロール および肥満度とそれぞれ推計学的に有意の関係を認めた。 そこで対象を比体重によりやせ群, 正常体重群, 肥満群 に区分してみると, 肥満群で摂取カロリーの多いもので は TG レベルが高いが, やせ群, 正常体重群ではこの ような傾向を認めなかった。一方, カロリ一の多鿒にか かわらずやせ群より正常体重群, さらに肥満群のほうが より高い TG レベルを示した. 年代別にみた場合, TG レベルは肥満群でもっとも高く加令とともに TG レベ ルの上昇を示すが, やせ群, 正常体重群では加令に伴う TG レベルの上昇を認めなかった。 また, 肥満群に打い ては, コレステロールレベルの上昇に伴って TG レベ ルの上昇する傾向が認められた。

次に, pre- $\beta$ リポ蛋白出現に関して, TG レベル, 比 体重, カロリ一, 炭水化物, 脂肪の影響を推計学的に検 討した結果, TG, 比体重, カロリーにそれぞれ有意の 関係があることが認められた，すなわち，TG レベルが 高くなるほど pre- $\beta$ の出現頻度が增し，またやせ群よ り正常体重群, さらに肥満者群に pre- $\beta$ の出現頻度が 増すことがわかった，カロリーについても同様に, 低力 ロリー群より正常カロリー群, さらに高カロリ一群に pre- $\beta$ の出現頻度が高いことが認められた. 炭水化物, 摂取脂肪の各レベルについては, pre- $\beta$ 出現に関して推 計学的に有意な関連をみなかった。

留問：五島雄一郎（慶大 内科）糖質と pre- $\beta$ リ ポ蛋白との間には関係がないとの結果であるが, 砂糖の 摂取量はどうか.

算問：木烟正義（岡山大 平木内科） TG $150 \mathrm{mg} / \mathrm{d} l$ 以下で pre- $\beta$ band のみられない例数の比率が $70 \%$ 以 上と見受けたが，pre- $\beta$ band の出現はもっと高いと思 らがいかが。

答: 徳久隆成 1) 砂糖の掑取量に対しては検討中で ある.

2) Pre- $\beta$ band 様態の判定については肉眼的に認め
演

題

$9: 191$

られないるのを（一）と判定した.

\section{0. 日本人高脂血症の疫学}

北川道弘 葛谷文男 吉峯 德 脇田 保

小林幸雄 前田周造 川原弘久 井口昭久

山田弘三

(名大 第 3 内科)

我々は日本人健康成人における高脂血症の頻度を知る ために, 昭和 45 年度冬に検診を行った. 名古屋市近郊 の某自動車工場従業員にて中等度の労働を行っている40 〜60 才の男性 858 名を選び, 早朝空腹時に採血して血 中脂質を測定した。ささらにトリグリセライド $120 \mathrm{mg} / \mathrm{d} l$ 以上の高トリグリセライド血症を示した 88 例について は, Sepraphore III を用いて, 血清りポ蛋白電気泳動を 行い, Fredrickson の高脂血症分類を試みた。

その結果コレステロールと燐脂質の間には有意の正の 相関を認めたが，燐脂質とトリグリセライド技よびトリ グリセライドとコレステロールの間の相関度は低かった。 総数 858 名の5ち, 異常と判定されたのは 113 例 (13 \%)であり，そのうちわけは I 型の疑い $2.7 \%$ ，II 型 $36.3 \%$ ，III型 $13.3 \%, I V$ 型 $42.5 \%, \mathrm{~V}$ 型の疑い $5.3 \%$ であった．以上の結果から，いわゆる健康人の中でもか なりの頻度で高脂血症を認めるので, これらの人々の健 康管理上も重要であるらと考觉られる。

問：中村尃久（熊本大 体䓄医研） コレステロー ル值の正常上限界を $250 \mathrm{mg} / \mathrm{d} l$ として扣られるが, 最近 の他の研究者の発表では 220 あるいは $200 \mathrm{mg} / \mathrm{d} l$ と低 い傾向であるようだがいかがか。

算問：五島雄一郎（慶大 内科） Type I とVが多 い上らに思われるが, chylomicron を調べたか, 測定の 際食事をたべていなかったか。

答: 北川道弘 (1)先生の扔っしゃると打り，コレステ ロールの上限に関しては $220 \mathrm{mg} / \mathrm{d} l$ 前後が適当ではない かと思 5.

(2) Type I および Vは疑いであり，これらの例につ いてはさらに検討したいと思う。

\section{1. 人間ッック受診者の血中脂筑に関する模討 \\ 大川日出夫 土屋博文 原田歳久 道川建一 安井厳野口八郎金子盾三 （永寿総合病院 内科）}

動脈硬化症と脂質代謝異常とは密接な関係があること は近年諸家の報じているところである. 我々は昭和 44 
年から当院人間ドック受診者に，トリグリセリドを従来 から測定していたコレステロールと合わせて測定を行っ ている. 今回は人間ドック受診者の血中脂質と年令およ び肥満との関係, ならびに血中脂質検查の成績と各種臨 床検查所見との関連について検討を行い報告した。

対象は 200 名で男が 183 名, 女が 17 名, 平均年令 は 49.1 才, やせが 48 名, 正常体重 93 名, 肥満 59 名であった。トリグリセリドはアセチルアセトン法で測 定し $150 \mathrm{mg} / \mathrm{d} l$ 以上を異常とした.

200 名から明らかな糖尿病 型のもの 33 名をのぞく 167 名について各年代別, 各肥満度別にトリグリセリド 高值のものの頻度をみた. 年令との関係は著明ではなく, 各年代とも肥満度の上昇に伴って高率であった。やせと 正常体重との間，正常体重と肥満との間に有意の差を認 めた。

200 名を高血圧と正常血圧, 心電図異常と正常, 眼底 KW IIa 以上と I 以下, 糖負荷試験で糖尿病型を示し たものと示さなかったものとに分け，それぞれにおける トリグリセリド高值のものの頻度を調べ比較した. 高血 圧では正常血圧よりも頻度は高率であったが有意差では なかった，心電図異常と正常ではほは同率であった，眼 底異常では正常のものよりも高頻度であったが, 有意差 は認められなかった，糖負荷試験糖尿病型のものにトリ グリセリド高值のものが高率に認められたが, 有意の差 は示さなかった。

\section{2. 老人ホーム居住者ワ氏反応強陽性者の循環器所 見と血清脂留について}

蓮村幸尣 川室 優

（特別盖護老人ホーム愛全園）

松本晋三 長友淳彦 木田博和

（慈恵医大 第 2 内科）

老人ホーム居住者 250 名中 40 名のワ氏反応陽性者を 選び, 高血圧症以外の疾患をもたね 20 名のワ氏反応陰 性者を対象として，その循環器所見および血清脂質につ き比較検討した. 40 名はいずれも 65 才以上で, 感染後 20３0 年経過の者と推定され，その男女比は， 1: 1 で現在は治療を行っていない者である.今回胸部 X 線 所見において特徵的な所見としては，一般に梅毒の血管 変化として考えられる上行大動脈の変化および大動脈瘤 は40 名中皆無であったことであり，ただ大動脈弓部の 突出を 30\% 認めたという事実である。しかしながら， 心肥大は陽性群に 90\%, 陰性群に 45\% と大きな差異が
みられ, これは心肺係数の増大, 心電図所見からも裏づ けられる。 また心音図所見では，陽性群に Q-1 時間の 延長傾向を認めたほか, 大動脈弁閉鎖不全を 1 名認めた. また眼底所見に沶いても，陽性群により高血圧性変化， 硬化性变化を強く認めた, 血圧の 比較では, 最高血圧 $160 \mathrm{mmHg}$ 以上を示すものが陽性群で $52.5 \%$, 陰性群 で 30\% と陽性群に多いが, 最低血圧はむしろ陰性者で 高い. 血清脂質（総コレステロール， $\beta$ リポ蛋白, 中性 脂肪）の比較では，なんら有意の差を認めなかった。な お，以上いずれの検査においても陽性倍数との相関はみ られなかった。

これらの事実より, 65 才以上の無自覚, 無症候性梅 毒ではいわゆる梅毒に特徵的な血管変化を示すことは少 なく，むしろ動脈硬化拈よびそれに基づく心血管系変化 が, 陰性者に比してより強く出現するのがその特徵と考 えられた。

\section{3. 内因性高トリタリセライド血症の成因に関する 研究 (II) \\ 石川俊次 五島雄一郎 中村治雄 鬼塚卓明 竹内一郎 中村康正}

(慶大 内科)

肥満者に高 TG 血症が多いことはすでに多くの報告 があるが，非肥満者に高 TG 血症を認めることはあり， その高 TG 血症発生機序は, 肥満者に括けるとれと同 一と考穴られるかを糖代謝, FFA, IRI の面より検討し た. 対象は 104 名の 61 才以上の高令者, 甲状腺, 肝, 腎などの脂質代謝異常をきたす疾患を有するものを除外 し,さらに 50g OGTT で糖尿病型を示すものを除外し た.

肥満度と TG 值は, 相関係数 $\mathrm{r}=0.394$ で相関し, これは $1 \%$ 以下の危険率で有意であった。ささらに，50 OGTT 後の FFA の変動をみたが, 高 TG 血症群にお いては, 正常 TG 群に比べ FFA 減少はゆるやかであ った。これを肥満群, 非肥満群に分けて検討してみたが, FFA の減少は高 TG 血症群では肥満の有無にかかわら ず, 正常 TG 血症群に比較してゆるやかであった，GT $\mathrm{T}$ 後の IRI の変化をみると, 非肥満者では高 TG 血 症群はしからざる群に比較して 1 時間後に低值であり, 肥満者では高 TG 血症群のほうが，しからざる群に比較 して高值であった，以上より，糖負荷後の高 TG 血症 群にみられる FFA 減少が軽度であるといら現象は，肥 満といち因子のみに影響されていないことがわかった。 